\title{
Reflections on the questionnaire at the workshops: Methodology for assessing the campus sustainability from the perspective of multi-level antifragility
}

\author{
Author: Robert Daniel Poskart
}

\begin{abstract}
Aim: The author provides a critical reflection of the questionnaire discussed at the workshop "Methodology for assessing the campus sustainability from the perspective of multi-level antifragility" held on Friday 13 May 2016 at the WSB University in Wrocław. The aim is to make a general diagnosis of the current situation in higher education in Poland, and to propose a direction of change than can enable its survival and improve its quality.

Design / Research methods: In the article, the author gives his personal reflections regarding the research questionnaire discussed at the workshop "Methodology for assessing the campus sustainability from the perspective of multi-level antifragility" in the context of the viability of higher education in Poland.
\end{abstract}

Conclusions / findings: The author selected, in his opinion, the most important elements of the questionnaire discussed at the research workshop. The main conclusion is that significant changes seem to be necessary due to the dynamic developments in the external environment, in particular the declining number of students resulting from the deepening demographic decline.

Originality / value of the article: The article provides critical feedback on an innovative approach towards research on campus sustainability.

Keywords: higher education, demographic decline, external environment JEL: I23, J11

\section{Introduction}

In this article, the author presents his personal reflections regarding the functioning of institutions of higher education in Poland in the context of

$\begin{array}{llr}\text { History: } & \text { received } & \text { 2016-10-14, } \\ \text { corrected } & \text { 2016-11-26, } & \text { accepted } \\ \text { 2016-11-26 } & & \end{array}$

the changing socio-economic environment. The subjective views on the issues are based on personal experiences with management and economics studies, as well as participation in the methodological workshop on 
"Methodology for assessing the campus sustainability from the perspective of multi-level antifragility" organized by the WSB University in Wrocław on 13 May 2016. About 24 academic teachers and higher year students from The Netherlands, Kazakhstan, Lithuania, Mexico, Germany, Poland and Turkey participated. During the workshop, based on an extensive research questionnaire, different determinants of viability of institutions of higher education as well as their impact on the sustainability of the external environment were analyzed and discussed in detail. In this article, the most important issues, in the opinion of the author, are discussed, as they are crucial for the competitive position of institutions of higher education and their capacity to survive in a dynamically evolving external environment. In the next sections, the following issues will be discusses: knowledge and education, mistakes and learning-by-doing, different types of fragilities and job market.

\section{Reflections regarding knowledge and education}

The statement that changes appearing in the world take place with such an intensity and speed in so many areas that science (and in particular higher education) cannot keep up with them is a truism. However, it may be that the disproportion in the inability to keep up with these changes in the external environment are fundamentally different in, for example, the highly developed Anglo-Saxon countries and former Communist countries such as Poland. This becomes more and more clear in the current processes of transformation in higher education, and may even become more apparent in the changes which are necessary in the future. While transformation has taken place in the economic sphere since the beginning of the 1990s, stimulated by strong competitive pressure from other European countries as well as the global market (see Winiecki 2012), a question is why significant changes have not taken place in higher education.

There are many factors that may explain the relative status quo in higher education. First of all, changes take time. Second, there should be fertile soil for making changes, in particular when these changes should be as "painless" as possible (see Furubotn and Richter 1997, Platje 2004). Of course, it can be argued that many changes have taken place. However, there exist great challenges in the near future (Denek 2012). It can be observed that system of higher education has not transformed in such a way that it has strengthened its viability. The current demographic decline may verify whether this is the case. The 1990s were the "golden era of Polish higher education" due to the massive increase in the number of students. This was the effect of, among other things, the demographic boom. As there were more students than available places at state universities, deep transformation was not necessary. This situation had as a consequences that a large amount of private institutions of higher education appeared, euphemistically called "non-public" (in the academic year 2014-2015 there were over 300 of such private institutions of higher education (Główny Urząd Statystyczny 2015: 30). ${ }^{1}$ Thanks to accreditation by the responsible state commission, these private institutions could offer the same studies and diplomas with the same value on the labour market as state universities

\footnotetext{
1 In the academic year 2014-2015, 302 non-public institutions of higher education were functioning in Poland. In total, 359,178 students enrolled, 13,071 academic teachers employed while 122,650 students graduated and obtained a diploma (Główny Urząd Statystyczny 2015).
} 
(also called public universities). This "golden age" has passed. Currently, the number of students is much lower, and the situation for many universities and colleges, in particular private ones, is dramatic. The whole branch (public and non-public universities and colleges) functions in an environment of demographic decline. This decline is expected to have its low in the years 2020-2022 (Główny Urząd Statystyczny 2015a: 4). ${ }^{2}$ This may create a great challenge for in particular private universities and colleges, as state universities will probably be able to offer as many places to study as there will be new students by that time. This is a serious threat to the viability of these universities, as without students they are not able to survive. This threat creates incentives for change, which should have taken place a long time ago.

Regarding the questions concerning the dilemma between creating knowledge and creating new graduates (new diplomas), it seems that both are important for the viability of a University. On the one hand, a high level of education and knowledge creation is important for the so-called "categorization" of the university, which influences the level of finance departments, faculties and whole universities obtain. The more faculties of a university belong to the highest category, the more funds a university obtains for scientific research (both private and public universities obtain financial support). The second component influencing the level of financial support

\footnotetext{
2 According to data from the Main Statistical Office, the number of graduates from secondary school will amount to 350,000 in the year 2020-2022. At this moment (2016) this number is 412,000 . Thus, assuming a similar trend in the schooling coefficient, the number of potential students is expected to decline by about 15\% (Główny Urząd Statystyczny 2015a).
}

is the number of students. The more students, the higher the financial support. It can be observed that most universities focus on attracting as many students as possible, in order to keep the different studies they have on offer. This tends to trade-off with the quality of education, in turn negatively influencing the level of knowledge obtained by graduates. This will probably have a negative impact on the value of the diploma of many universities on the labour market.

Another important issue discussed during the workshop is the use of system approaches in teaching. While formally many standards are fulfilled on paper, such a system approach is not often applied. Not only in teaching issues of sustainable development, but also in the creation of the curriculum. Many documents are created (syllabuses, etc.) exactly describing the content of different courses in accordance with the ministerial $\mathrm{Na}$ tional Qualification Framework (KRK - Krajowe Ramt Kwalifikacyjne). At each university detailed descriptions are provided which kind of knowledge, abilities, social skills, etc. the student should acquire during classes. However, reality may be completely different from what is written in the documents. A reason is the quality of teachers, but also the tendency to reduce teaching hours in order. Observation of lecturers does not take place often, or only formally "on paper". Questionnaires among students do not always provide a complete picture of the situation. And it remains a question whether students and lecturers are interesting in changing the situation. It is questionable whether lecturers completely understand the $\mathrm{Na}$ tional Qualification Framework, and no integrated approach towards the curriculum is used, as this would require extra effort. Furthermore, when being too tough for students by failing them, this may threaten certain study 
programmes. When not changing this by way of using a system approach towards the creation of the curriculum, this may create a long term threat to the viability of the university the moment more knowledge is required by the labour market.

Important for the viability of institutions of higher education is business orientation of study programmes, as this improves the opportunities for students on the labour market. A challenge in improving the business orientation, like with increasing knowledge in general, is the reduction in teaching hours for core subjects due to the aim of cost reduction in the face of declining student numbers. While this cost reduction may be necessary for university viability, it may trade-off with students' basic knowledge. In particular developing critical thinking and discussion may require more intensive student-teacher interaction. The current curriculum may not be adapted to the demands from the side of business. For example, in financial sciences there is a lack of use of advanced platforms for so-called integrated management in the educational process. Such a platform allows for multi-level economic-financial analysis. Also, trading platforms should be used in order to make students acquainted with the complex and dynamically changing financial system. The introduction of use of such platforms is a challenge, due to lack of financial resources in higher education, in particular in case of smaller universities. Furthermore, different decision-makers may not appreciate the importance of such platforms, as the costs are directly visible, while the benefits of such an innovation and the impact on attracting new students are rather more indirect and uncertain.

Also, the contents of courses needs to be adapted in order for the students to find a job in the field of their studies. The student should possess skills and abilities that enable to start working without significant extra time and outlays spent of trainings required by the employer. In this context, increased cooperation between university and business is requires, as at the moment many study programmes seem to provide knowledge which is difficult to apply in business practice.

\section{Reflections regarding mistakes and learning-by-doing}

One important element, in the opinion of the author, that is important for university viability is ignorance of critique from students or staff by university management. The moment critique is treated as a kind of insubordination, and/or is just ignored, this may create problems. During the years of the demographic boom, student critique could be neglected. However, as nowadays there is a struggle for students, this may negatively influence the number of students. While it may be argued that teaching staff can be easily replaced (e.g., more teachers on the labour market due to the decline in number of students), the best teachers may become demotivated, and eventually leave for a job in, for example, business. This in turn negatively influences the attractiveness and quality of studies. A reason for ignorance of critique may be that the management of many universities do not really see the need for continuous improvements in the educational programme and the organization itself. In particular when already working, say, for 30 years at a university, the management has the experience of the "golden age" while already being in their 50 s or 60 s. Also when consciousness of the problems and the willingness to change exist, a lack of habit and experience with making critical analyses of the university viability may be a factor hampering change. 
Another issue is students asking questions during classes. While management may ignore critique from weaker stakeholders such as students and lower level teaching staff, students do not have the habit to ask questions during classes. From time to time, the most motivated students tend to ask questions. This may show that paradoxically, when studying economics or finance, there is no real interest in the subject. It should be researched whether this is related with the knowledge required by the labour market, as well as the question whether a student studies in order to obtain knowledge, or rather in order to obtain a diploma. However, another determinant of the few questions asked during classes may be the Master-Student relation, where asking questions can be interpreted as questioning the authority of the teacher.

This last issue also needs deeper study. When interested students ask questions to a well-prepared lecturer, the questions may be appreciated as this lecturer then has an occasion to show a high level of knowledge by providing specific and practical examples. When, as has been mentioned on different occasions by lecturers of different universities, the lecturer is "one lecture in advance of the student" as he/she has read the materials before class, asking questions can lead to inconvenient situations. While this may be a kind of urban legend, research is needed whether such phenomena exist, and at what scale.

An issue is whether students prepare for classes. An interesting question in the questionnaire related to this is whether reading a textbook is more useful than a lecture. This is unlikely to be the case, and depends on the type of lecture. In the ideal case, the lecturer is an expert in the given field of study and students interested in the subject, while classes inspire further search for knowledge in literature. However, when an incompetent lecturer provides classes, it may happen that lectures are a waste of time and it may be better to read the literature.

The next issue, which is rather complex, is making mistakes and the reaction to mistakes by superiors. While it may be argued that it is better not to make mistakes, only people not doing anything do not make mistakes. This seems often to be understood, that mistakes are a normal thing, and no extreme reaction is likely to appear. However, when a mistake appears, for example, in a project co-financed by external sources (e.g., ministry, European funds) this may lead to exclusion of a university from future funding. In such a case, often a kind of collective responsibility is applied, where besides the persons responsible also others are punished. While this is understandable due to the huge impact on the university, such a reaction can create anger and frustration among employees. However, these things are unlikely to be discussed in public.

\section{Reflections regarding different types of fragilities}

One element in the discussion at the workshop was the influence of the university on the sustainable development of the external environment, in particular the city in which it functions. Until not such a long time ago, the impact on the environment was rather negative, due to lack of waste management and low energy efficiency of buildings. However, during the last decade many investments improving the energy efficiency can be observed, more solar power is being used, while waste segregation has been introduced. The moment universities start to use unused buildings in the city centre, and renovates them, this positively influences urban 
development. This can be observed in the city of Opole in Poland.

One fragility identified concerns the influence of a few good lecturers on the level of education. Although lecturers can be replaced, in particular in a situation of demographic decline, for many types of studies specific knowledge is needed. The impression exists that many programmes drive on a few specialists, knowing the ins and outs of the specifics of the programme. When they would disappear, replacement by lecturers with less talent and knowledge may significantly reduce the competitiveness of such a study programme, which also weakens the university.

An interesting question is whether the situation in higher educational institutions can be worse than it is at this moment. As mentioned, due to the demographic boom reforms stayed behind. These reforms probably will need to take place, due to the increasing competition between universities resulting changes in the external environment, in particular the declining number of students. The decreasing amount of students is not only the result of the demographic decline, but also emigration as well as the reduced interest in higher education. Furthermore, the expected earnings after finishing higher education compared to the earnings of people not finishing their studies tends to become less attractive. The number of students as a percentage of the total amount of people in the student age has been declining from $49.2 \%$ in $2013 / 2014$ from 53.8\% in 2010/2011 (Wilkin 2015: 5).

Another issue discussed is the level of administrative support for research grant application and management. While such support is very important, it is already difficult for small institutions of higher education outside the educational centers in large metropolitan areas to obtain such grants.
An important criterion in the decision is the experience of the project manager in managing research project, or participation in such projects. Even very good proposals may be rejected because of this criterion. How, then, to obtain experience when experience is an important condition to obtain a grant? This is difficult due to the little amount of money available from the state directly used for financing research at universities, and the increasing reliance on the mentioned grants.

\section{Reflections regarding the job market}

An interesting issue is the relations between knowledge required by the labour market and the incentives for students to acquire knowledge during their studies. In the discussion at the workshop it was argued that when the labour market requires knowledge, this may positively influence the motivation to study for knowledge, and not only for obtaining the diploma. Important in this context are two factors: the topic of studies and the situation on the labour market. When the demand for a certain profile of studies is high, then students will probably rather easily find work when graduating. This may reduce the knowledge requirements. A complicating factor is that employers in need for a certain type of graduate also may have its own training programme for new employees. This complicates the research on relation "labour market demand" and "incentives for acquiring knowledge by students". The moment a student graduates from a less desired direction of studies, acquaintances, friends and family may be relevant in finding a job. In particular when this is a job in the public sector, connections may be more important than knowledge. In the private sector knowledge may be more important in order to keep a job, as it may influence the revenues and costs of the private owner. 


\section{Concluding remarks}

In this paper, important determinants of the competitive position of institutions of higher education were presented, supporting organizational viability. Their importance and significance are disputable and need deeper elaboration. Workshops on the viability of higher education institutions, like the one discussed in this article, may be an important instrument for the future viability and development of higher education. In particular decision-makers should participate in such workshops. This allows for confronting propositions for change with the real possibilities

\section{Bibliography}

Denek K. (2012), Transformacja systemowa szkolnictwa wyższego (System transformation of higher education), Uniwersytet im. Adama Mickiewicza w Poznaniu, Poznań, https://repozytorium.amu.edu.pl/bitstream/10593/6038/1/Transformacja-M-E-K-2012.pdf (23.09.2016).

Główny Urząd Statystyczny (Main Statistical Office) (2015), Szkoły wyższe i ich finanse w 2014 r. (Institutions of higher education and their financing), Główny Urząd Statystyczny, Warszawa.

Furubotn E., Richter R. (1997), Institutions and economic theory - the contributions of the New Institutional Economics, The University of Michigan Press, Ann Arbor.

Główny Urząd Statystyczny (Main Statistical Office) 2015a, Dzieci w Polsce w 2014 roku. Charakterystyka demograficzna (Children in Poland in 2013. A demographic characterization), Głowny Urząd Statystyczny, Departament Badań Demograficznych i as well as the willingness to introduce such changes. Detailed analysis of the fragilities embraced by the questionnaire can create a basis for the decision-makers for developing strategies and aims. However, a condition for change is the willingness of critical assessment of and discussion about the institution of higher education in question, as well as the willingness to change. This element is partly included in the questionnaire - the capacity for critical discussion and learning from mistakes. Without the capacity for eliminating fragilities, institutions of higher education have a lower probability to be viable in the changing external environment.

Rynku Pracy, Warszawa, http://stat.gov. pl/obszary-tematyczne/ludnosc/ludnosc/dzieci-w-polsce-w-2014-rokucharakterystyka-demograficzna,20,1. html (23.09.2016).

Platje J. (2004), Institutional change and Poland's economic performance since the 1970s - incentives and transaction costs:, CL Consulting i Logistyka, Wrocław.

Wilkin J. (2015), Finansowanie szkół wyższych ze środków publicznych studia, analizy i propozycje rozwiązań systemowych (Fincancing of institutions of higher education from public sources - study, analysis and proposals for systemic solutions), presentation of the project 15.10.2015, http:// www.rgnisw.nauka.gov.pl/g2/oryginal/2015_10/8d1892a0f5172f8688fbf3cda5459760.pdf (23.09.2016).

Winiecki J. (2012), Transformacja postkomunistyczna. Studium przypadku zmianinstytucjonalnych, Wydawnictwo C.H. Beck, Warszawa. 
Refleksje dotyczące kwestionariusza w ramach warsztatów:

Methodology for assessing the campus sustainability

from the perspective of multi-level antifragility

\begin{abstract}
Abstrakt
Cel: Autor przedstawia krytyczne przemyślenia dotyczące dyskusji nad kwestionariuszem, która odbyła się podczas warsztatów pt. "Methodology for assessing the campus sustainability from the perspective of multi-level antifragility" przeprowadzonych w piątek 13 maja 2016 roku na WSB we Wrocławiu. Celem artykułu jest postawienie diagnozy obecnej sytuacji szkolnictwa wyższego w Polsce oraz zaproponowanie kierunku zmian, jakie musiałyby nastąpić w przyszłości, by umożliwić jego dalsze przetrwanie i rozwój o charakterze projakościowym.

Układ / Metody badawcze: W artykule przedstawiono osobiste refleksje autora dotyczące zawartości kwestionariusza badawczego w kontekście problemu funkcjonowania szkolnictwa wyższego w Polsce.

Wnioski / wyniki: Autor wybrał najważniejsze jego zdaniem zagadnienia dostępne w formularzu omawianym na warsztatach w ramach projektu badawczego. Głównym wnioskiem wynikającym z prowadzonych rozważań wydaje się być pilna potrzeba zmian w szkolnictwie wyższym wymuszonych coraz bardziej dynamicznie rozwijającym się otoczeniem zewnętrznym. Szkolnictwo wyższe sprostać musi wyzwaniom pojawiającym się wraz z malejącą liczbą studentów, będącą pokłosiem kryzysu demograficznego w Polsce.

Oryginalność / wartość artykułu: Artykuł przedstawia krytyczną opinię na temat innowacyjnego podejścia do badań nad zrównoważonego rozwoju kampusu.
\end{abstract}

Słowa kluczowe: Szkolnictwo wyższe, niż demograficzny, otoczenie zewnętrzne 